PSYCHE, VOL. XIV

PLATE II

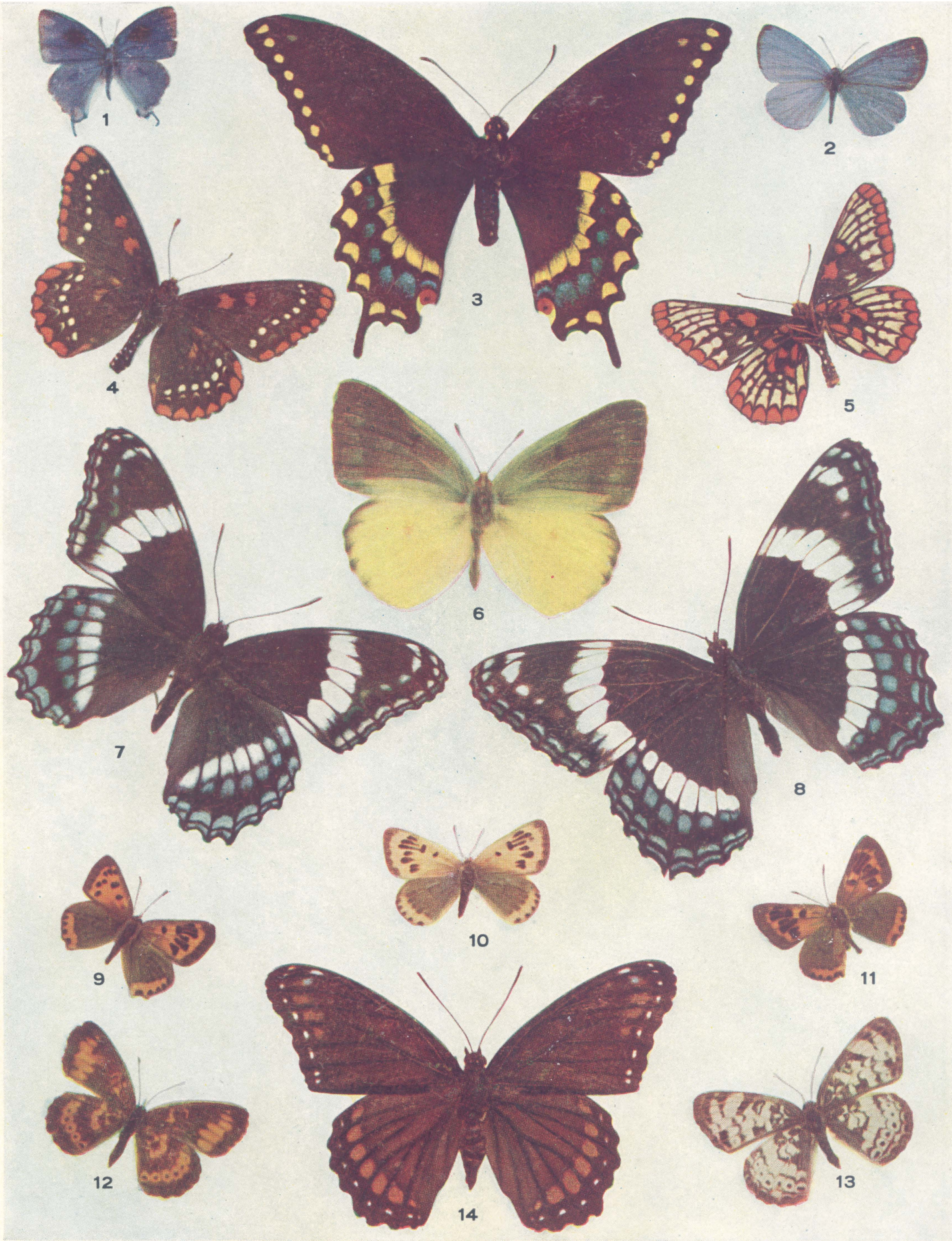

A FEW RARITIES 


\section{EXPLANATION OF PLATE II, WITH DESCRIPTION OF NEW VARIETY OF LIMENITIS URSULA.}

BY H. H. NEWCOMB, BOSTON, MASS.

Fig. 1, Thecla critola, Hewitson, $\sigma^{\nearrow}$, Patagonia Mts., Arizona. (E. J. Oslar.)

Fig. 2, Lycaena pseudargiolus var. arizonensis, Edw., hermaphrodite; left side ${ }^{\top}$, right side + . Huachuca Mts., Arizona. (E. J. Oslar.)

Fig. 3, Papilio polyxenes, Fabr. $\sigma^{\top}$, aberrant; lacking the inner row of yellow spots across the primaries. Albany, N. Y. (J. H. Cook.)

Fig. 4, Melitaea phaeton, Dru:, ठ ${ }^{\top}$, aberrant; having but one row of white spots across the wings and with the marginal lunules absent. Milton, Mass. (H. H. Newcomb.)

Fig. 5, M. phaeton var. superba, Strecker, $0^{\nearrow}$, (under side). Milton, Mass. (W. D. Denton.) I have another from the same locality on which the white is more diffused but less distinct.

Fig. 6, Colias philodice Godt. \& aberrant; the primaries being melanic. Sharon, Mass. (A. C. Sampson.)

Fig. 7, Limenitis ursula var. albofasciata, Newcomb, Ð $^{7}$. (Previously figured, uncolored, Psyche, Vol. XI, Pl. III.) Sharon, Mass. (A. C. Sampson.) See description on next page.

Fig. 8, same as above, 우. Bedford, Mass. (L. W. Swett.)

Fig. 9, Chrysophanus hypophlowe Bdv. $\sigma^{\top}$ aberrant; left side normal, right side var. fasciata Streck. Sharon, Mass. (A. C. Sampson.)

Fig. 10, C. hypophlaeas var. fasciata 우, albinic. Princeton, Mass. (L. W. Swett.)

Fig. 11, C. hypophlaeas var. fasciata, ठొ, Wellesley, Mass. (H. H. Newcomb.)

Fig. 12, Phyciodes tharos, var. packardii Saund. $0^{\top}$. Sharon, Mass. (A. C. Sampson.)

Fig. 13, P. tharos, Dru. 우 albinic. I believe this example of albinism to be unique in this species. Dorchester, Mass. (H. H. Newcomb.)

Fig. 14, Limenitis sp. $0^{\top}$. This butterfly which has been previously figured in Psyche (Vol. XI, Pl. 1, fig. 4) but uncolored, may be a cross between archippus Cram. and ursula Fabr. as suggested by Field (Psyche, Vol. XI, p. 1). There are certainly some grounds for this assumption: for instance the marginal row of white dots on the upper surface is distinctly traceable to archippus, while on the under side 
the ferruginous basal patches are characteristic of ursula. Except for the latter I should unhesitatingly say it was a suffused form of archippus. Taken at Sherborn, Mass., by the late A. L. Babcock in 1895 and presented to me by A. P. Morse. There is in the Academy of Arts and Sciences, Brooklyn, N. Y., a similar specimen taken by Ernest Shoemaker at Washington, D. C.

All of the above diurnals are in my collection.

L., ursula var. albofasciata new. (Plate II, figs. 7 and 8). A dimorphic form of ursula having a mesial white band, of varying width, extending across all the wings from near the middle of the costa to the inner margin of the hind wings about one-third the distance from the anal angle and reappearing on the under surface. Outside the white band, on the upper side of the secondaries, there is a row of light blue spots sometimes merging into a continuous streak. These are replaced below by the usual ferruginous spots of ursula. There is very little, if any, red on the secondaries above as on the arthemis $\sigma^{\pi}$.

Habitat, so far as reported, Mass., eastern N. Y., and vicinity of Jersey City. Types, $2 \sigma^{\top} \sigma^{\top}$ and 2 우 우 in my collection.

Co-types $10^{\top}$ and 1 , , Museum of Comparative Zoology, Cambridge, Mass., and 1 t , collection of Henry Wormsbacher.

This variety is readily distinguishable from the species it closely resembles, L. arthemis Drury, by one familiar with both insects. On fresh specimens the ground color of the wings above in the basal area has a very different tone. On ursula and its varieties there is a bluish cast while on arthemis the same dark or nearly black region has a brownish hue. Other points to be considered are size, habitat, width and position of the white band, the amount and shade of the blue on the secondaries above and as before indicated the presence or absence of red on males.

Proserpina Edw. is generally conceded to be a variety of arthemis (a view which I take), although some writers have suggested that it might be a hybrid with ursula. The strongest argument to support this theory is the fact that the ranges of the two species overlap. No such claim can be made with regard to albofasciata, however, as it has been taken in localities where arthemis is unknown, such as Staten Island, Long Island, N. Y., and Jersey City. It has also been taken near Boston. Has arthemis? It seems very doubtful. All the recorded captures I have been able to trace have turned out to be albofasciata. There are several such specimens in the Museum of Comparative Zoology at Cambridge - one from Malden, another from Wollaston, etc., wrongly identified as arthemis. We must, then, revise our records.

If albofasciata is a sport we should expect to find intergrades; and we do find them in abundance, from those having the merest trace of a white band across the 
fore wings to such examples as fig. 8 . Fully 20 per cent. of the ursulas taken by me in eastern Massachusetts exhibit a tendency towards the development of this character.

It has been my privilege to examine a fine specimen of this variety, taken by Henry Wormsbacher near Jersey City, of which he writes as follows: - "The butterfly I captured has nothing to do with arthemis, but is a true ursula, more green in color like the form viridis and with broad white bands across the two wings. There are no markings whatever in the specimen which are found in arthemis and it is by all means a new variety. I do not think it necessary to make a sketch or photo of same, just take a greenish ursula o and put white bands on it."

In view of the above facts and after several years of careful investigation, including the examination of scores of specimens, I am led to the positive conclusion that interbreeding of ursula and arthemis is in no way responsible for this variety.

\section{THE NEWARK ENTOMOLOGICAL SOCIETY'S LOSS.}

THE headquarters of the Newark Entomological Society on the fourth floor of the Newark Turn Hall was completely destroyed by fire in the early morning of June 3rd, 1907. The conflagration not only demolished the entire building but resulted in the loss of three lives.

The property of the Society consisted of a forty drawer cabinet containing one thousand specimens of Lepidoptera and two thousand five hundred specimens of Coleoptera, mostly representing local forms, besides a small collection in other orders; also a bookcase with one hundred and ten bound volumes and three hundred and sixty-five unbound volumes and pamphlets. All of this property was consumed by the flames except a few books that were in the hands of members. This collection was the accumulation of over twenty years of the Society's existence and as the loss is only partially covered by insurance it will be a long time before it can be replaced. Some of the books, perhaps, can never be obtained again.

The Society will be exceedingly grateful for any help in the way of rebuilding the library that may be given it. Entomologists are earnestly invited to send separates of their papers or other publications that they may have in duplicate for which the costs of transmission will be gladly refunded. Until the Society is again established in permanent quarters, parcels should be addressed to the secretary at New Brunswick, New Jersey.

John A. Grossbeck, Sec'y. 

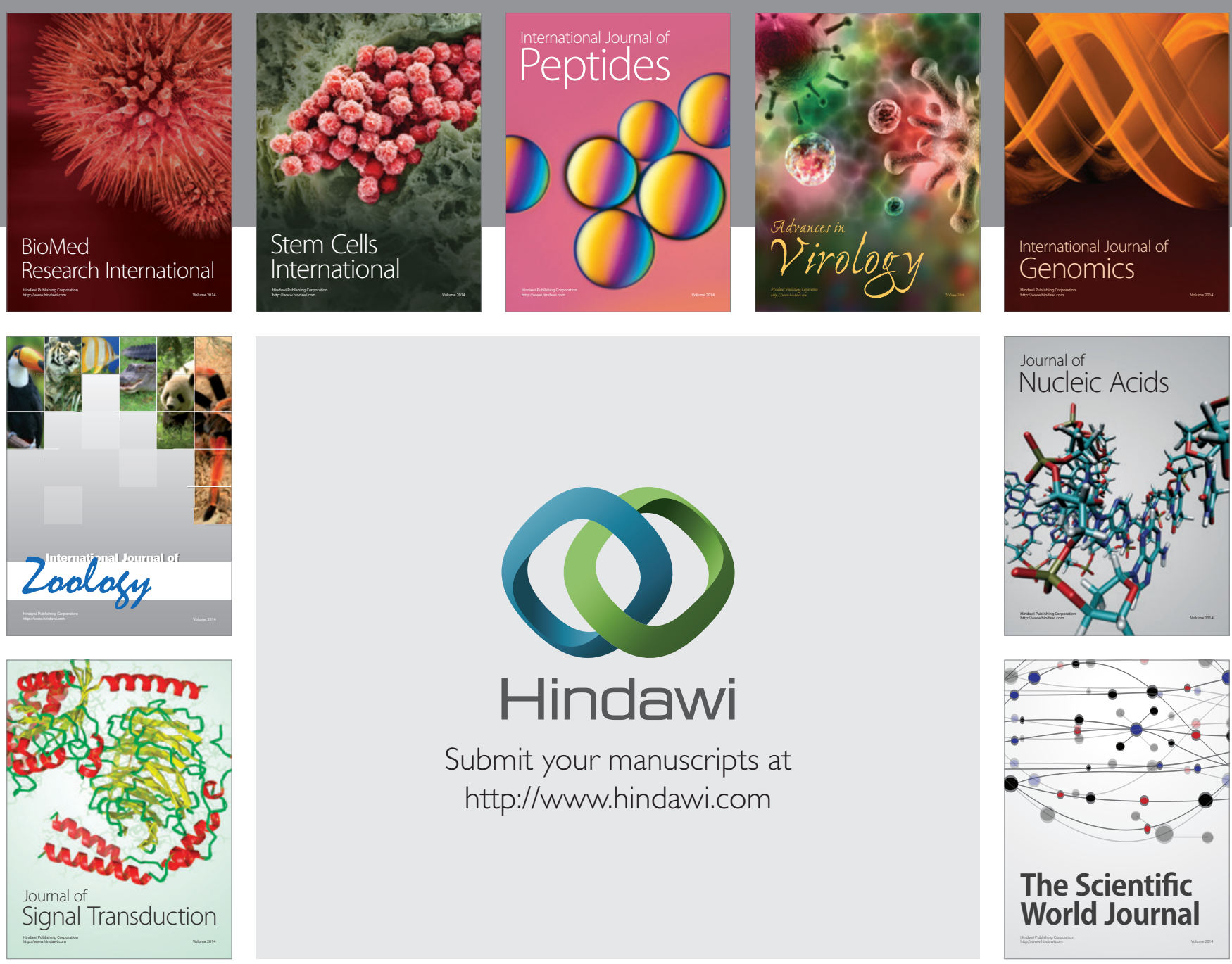

Submit your manuscripts at

http://www.hindawi.com
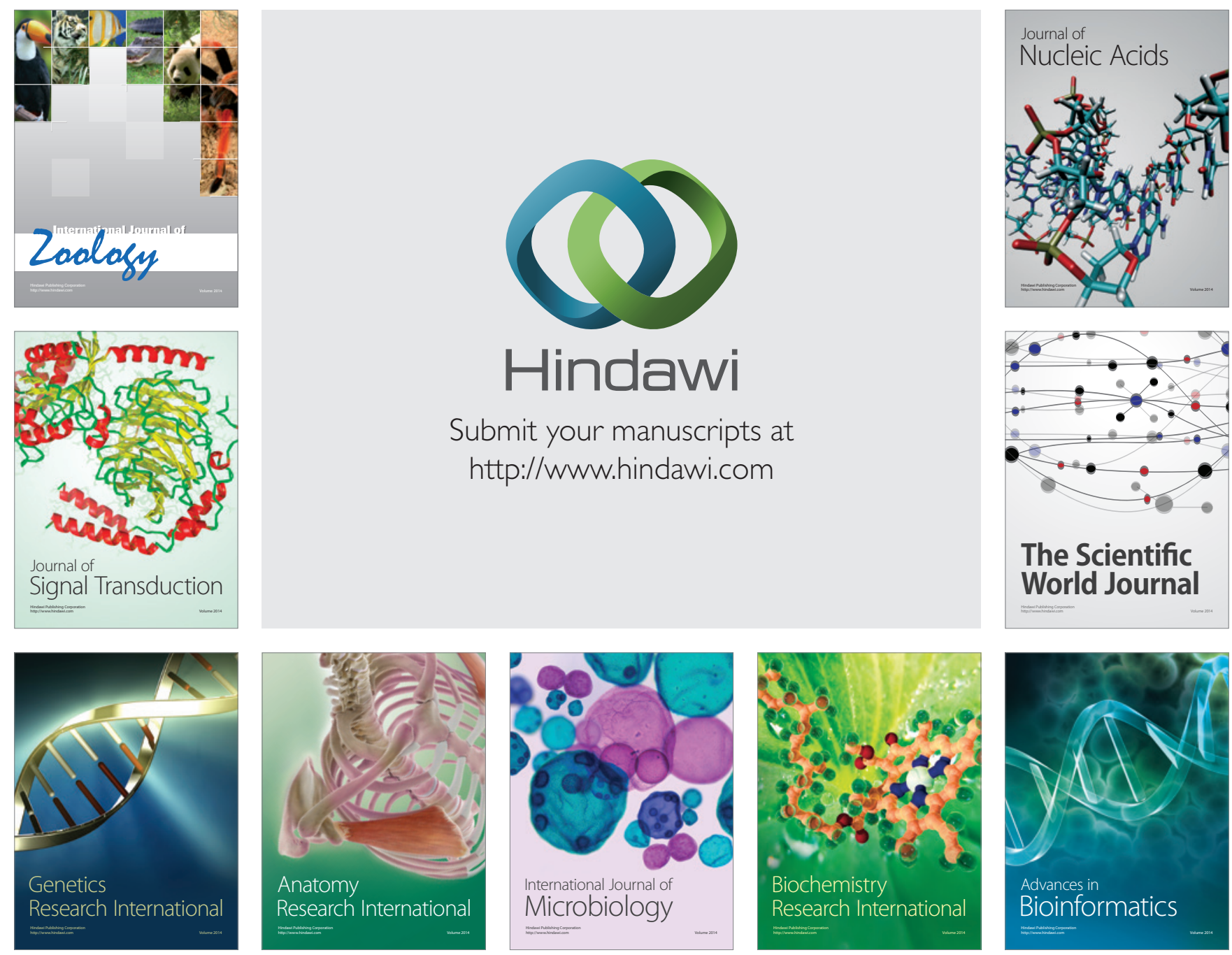

The Scientific World Journal
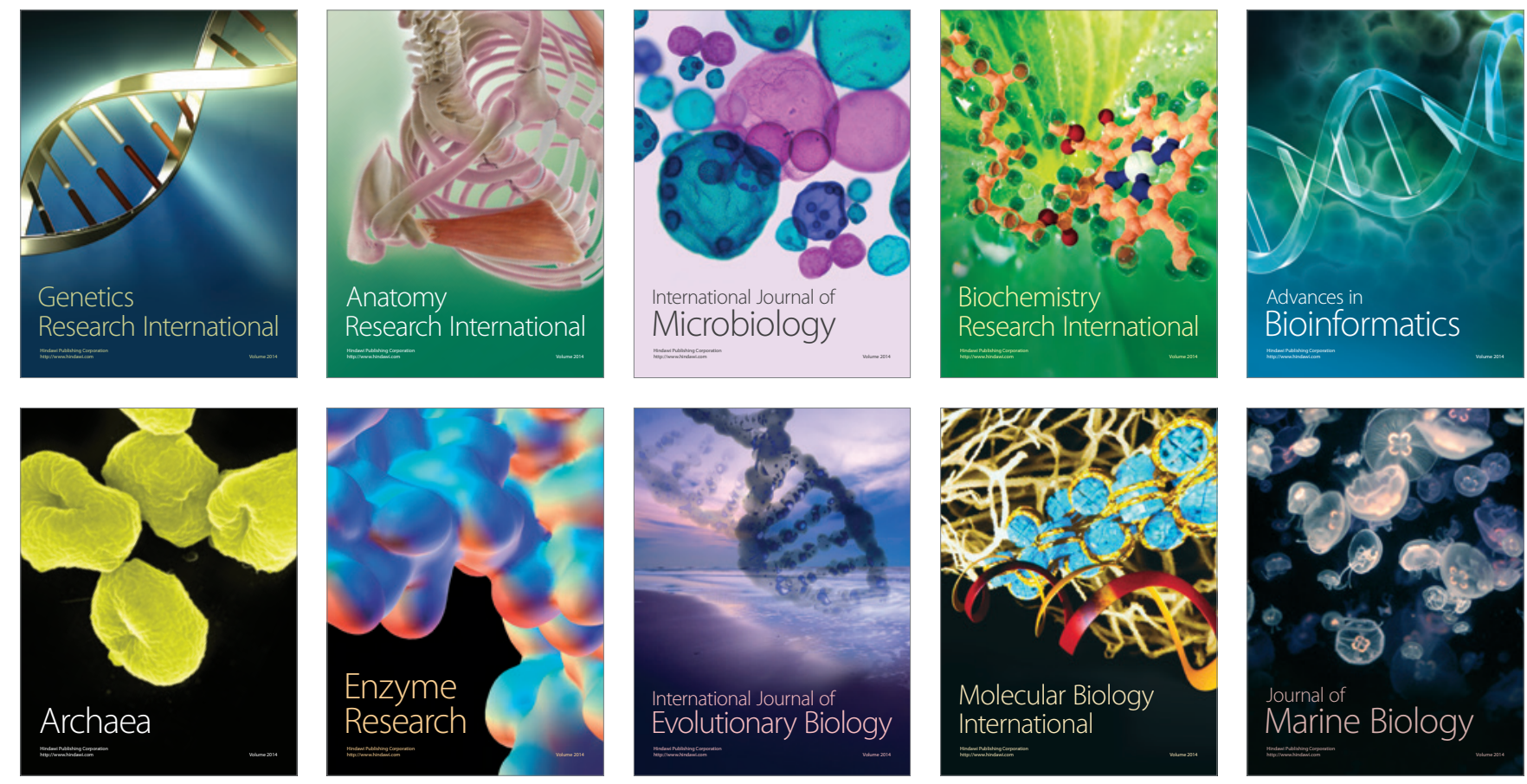